\author{
Даниэль Вайс \\ Университет в Цюрихе, Институт славистики \\ (Швейчария, Цюрих) \\ dawe@slav.uzh.ch
}

\title{
КОНСТРУКЦИЯ С ПРЕПОЗИТИВНОЙ ОТНОСИТЕЛЬНОЙ КЛАУЗОЙ
}

В статье рассматриваются два типа неканонических рестриктивных относительных предложений в разговорной разновидности современного русского языка: препозиция относительной клаузы с местоимением который и относительная клауза с внутренней именной вершиной. Первый тип отличается четкой дискурсивной функцией, поскольку относительная клауза здесь служит для выделения нейтральной или контрастной темы. Этим объясняется исключительное оформление местоимения в именительном падеже. Главная клауза часто содержит референциальную поддержку относительной клаузы в виде анафорической ссылки, построенной личным или указательным местоимением, но такая поддержка отнюдь не обязательна. Конструкция с внутренней именной вершиной выступает преимущественно в пре- и интерпозитивных относительных клаузах. Попались два примера в постпозиции с повторением антецедента в главной клаузе, функционирующие как нерестриктивные относительные клаузы; их приемлемость сомнительна, поскольку они могут быть обусловлены случайным неконтролируемым отклонением. С другой стороны, следует отметить, что именно этот подтип был в исторических источниках формально-канцелярского характера весьма распространен (для большей наглядности процитирую: «А которой крестьянин сварит пиво не явясь, и на том крестьянине имати пени») и может даже сегодня употребляться в качестве сознательного обыгрывания архаизма; такой прием наблюдается в творчестве Л. Петрушевской. В последнем разделе статьи обсуждается употребление препозитивных относительных клауз в речи рассказчика и персонажей у М. Зощенко. Этот прием служит не для верного отражения живого узуса, а лишь для художественной стилизации устной речи, о чем свидетельствует отсутствие других неканонических конструкций относительных предложений из живой речи, и особенно использование многократных повторов тех же относительных клауз в качестве лейтмотива, характеризующего данного персонажа. Все примеры берутся из основного и устного подкорпусов «Национального корпуса русского языка», из хрестоматии «Живая речь уральского города» и из существующих описаний русской разговорной 
речи. Наблюдения над русскими данными дополняются типологическими комментариями.

Ключевые слова: относительная клауза, препозиция клаузы, выделение темы, русская разговорная речь, внутренняя именная вершина, антецедент, анафора, М. Зощенко, художественный прием.

В работах, посвященных синтаксическим особенностям разговорной разновидности русского языка, давно отмечен тип конструкции с препозицией относительной клаузы (ПОК). Речь идет о примерах типа:

(1) Которые фронтовики обойдутся таким зеркалом [Земская 1973: 84];

(2) Которые старики / они были недовольнье нами [Кручинина 1968: 84].

Такие построения отклоняются от нормы стандартного языка в двух отношениях: относительная клауза (ОК) предшествует главной клаузе (ГК), и, следовательно, относительное местоимение (ОМ) не имеет антецедента. Как видно, оно может зато сопровождаться анафорической ссылкой в главной клаузе (пример 2) и выступать без нее (пример 1); о второй возможности упоминается также в [Зализняк, Падучева 1979: 294]. Кроме того, встречаются и указательные местоимения в той же функции:

(3) Которые посмелее те / эти / они опять смеются [Кручинина 1968: 83].

Кроме того, автор допускает и инверсию внутри относительной клаузы, ср.:

(3а) Посмелее которые опять смеются.

И наконец, постпозитивный порядок тоже не исключен, ср.:

(3b) Опять смеются которые посмелее.

Если учесть все позиционные варианты ОМ и возможные местоименные или нулевые корреляты, получается максимально 16 различных формулировок ${ }^{1}$.

Итак, рассмотренные примеры отличаются от стандартной языковой нормы в двух отношениях: 1) допускается перемещение относительной клаузы в самое начало предложения, 2) может отсутствовать ее антецедент, т. е. именная опорная вершина (head) в главной клаузе, будь то именная группа вроде люди или указательное местоимение-коррелят (light head), ср. примеры 1, 3a и 3b. Такая характеристика напоминает поведение ОК с субстантивными местоимениями кто / что, ср. вполне нормативные варианты Кто посмелее, опять смеются <смеется> и Опять смеются <смеется>, кто посмелее. С другой стороны, препозитивное субстантивное местоимение кто может в принципе выступать в любом падеже, а для препозитивного местоимения который характерен лишь именительный падеж (см. ниже). Таким образом, в данной разновидности русского языка

${ }^{1}$ При постпозитивной ОК функция местоимений он и этот превращается из анафорической в катафорическую. 
вырисовывается частичный синтаксический параллелизм между ОМ который и кто / что. В семантическом отношении описанные клаузы всегда оформляют рестриктивные (определительные) ОК. В таких примерах, как 1 и 2, можно усматривать известную избыточность, поскольку ОМ может с успехом опускаться, ср.: Фронтовики обойдутся...; иначе обстоит дело с примером 3 - в силу морфологической неопределенности предикатного слова, ср.: *Посмелее опять смеются.

В существующих корпусах устной речи препозитивная конструкция выступает довольно редко. Так, диалоги, вошедшие в сборник [Китайгородская, Розанова 1999], содержат 98 (преимущественно регулярных) относительных предложений, а ПОК там вовсе не представлена. Зато она нашлась в хрестоматии [Шалина 2011] где имеется всего лишь 25 относительных предложений, причем из них 15 - нерегулярные [Weiss 2019]. Пример 4 содержит ПОК с последующей анафорой:

3. Д. Дькк и чё получатся / которая ругается / у ней ваще нет транспорта?

Искомый референт находится в довольно отдаленном предшествующем контексте: это соседка главного героя рассказа. Таким образом, ОМ выполняет реидентифицирующую функцию и служит как антецедент местоимения ней, которое здесь является необходимым для маркировки посессора. Иначе обстоит дело в следующем примере:

Г. О. Я тяплииу помазал / вода не так пристает / дождь лил сутки // которые помазанные / потрогал они не мокрые / знащчт не впитывалась вода Н. Стёкла | что ли?

Г. О. Да нет / деревянные эти.

Здесь очевидна коммуникативная неудача, вызванная отсутствием четкого антецедента: только после переспроса собеседника выясняется, что говорящий имел в виду помазанные им доски, но, видимо, не мог найти подходящего слова. Отметим, что соотносительное слово те также не помогло бы раскрыть желаемую референцию.

Устный корпус [НКРЯ] является источником многих примеров с ПОК, хотя не все результаты одинаково надежны из-за затрудненной проверки предшествующего расширенного контекста. Подкорпус «Устная непубличная речь» содержит шесть примеров, причем все - без анафоры в главной клаузе:

(6) Которая ехала стоя... перешла вперед и села... (Сборы в дорогу и поездка в транспорте, 2007);

(7) 53, Р2, жен.: Которые последние / я не взяла. Потому что я не знала / что надо их сюда с собой брать. Вот тут / которые в марте и ещзё здесь я... (Посещение врача, 2006);

2 Этот сборник отличается от остальных коллекций устных текстов прежде всего по социальному составу участников: среди них представлено много рабочих. Может быть, этим обусловлена высокая доля регионализмов, см. получатся = получается, и того пласта языка, который традиционно причисляется к так называемому просторечию, см. у ней (наряду с у ей, у ее и стандартного у нее). 
(8) 54, руководитель, мать, жен.: Которая в профкоме / сволочь. Слушай / я / наверное / выйду из профсоюза. Я говорю / «Здравствуйте / извините / что так произошло / вот». Этот Колесников / конечно / говорит / «Ну / как же / вам сегодня два раза звонили...» В десять утра ей сказали принести характеристики / представляешь? (Рассказ о работе, 2006);

(9) 77, пенсионер, Соколова, жен.: Которые перемёрли / которые на фронme / остались. Так что я / осталась одна совсем (Воспоминания о прошлом Е. Соколовой, 1981);

(10) 56, филолог, В, муж.: Которые ничего не знали / русского языка просто не знали / у нее сдавали научные работы (Разговор о знакомых, 1960-1980);

(11) 80, пенсионер, А., жен.: Вот. Потом вот эти консервы. Которые консервы куиали / все рак получили. Они были заражёньл. Все раком страдают. Вот от этого / и от пережитого / и вот мы остались отс... остатки / и в нас ничего нету натурального. У нас всё болит. Вся внутренность (Воспоминания о прошлом бывших работниц «Трехгорки», 1964).

Как видно, все рассмотренные до сих пор примеры разделяют один общий признак: ОМ в них выступает как субъект. По отношению к ГК наблюдается большее разнообразие: кроме отмеченного уже посессора в примере 4, падежная роль антецедента нигде не маркируется, но подсказывается валентностью предиката, поскольку наряду с субъектами здесь представлено и прямое дополнение (примеры 5 и 7: которые помазанные (ux) потрогал, которые последние / я их не взяла). Кроме того, ОМ однозначно указывает на пол и число референтов, см. пример 8.

Чаще ПОК встречается в более объемном подкорпусе «Устная публичная речь» (около 15 примеров). Они обнаруживают большую вариативность: так, кое-где появляется коррелят тот или анафора $о н$, ср.:

(12) Рабочий, № 1, муж.: ... Оттаяла тундра / значит / ну / и всё завалилось здание / и всё... Не выдержали колонные нагрузки / стали оседать / ну и люди. Которые гуляли / естественно / не успели выпрыгнуть / завалилось здание и всё (Евгений Лебедев. Рассказ о жизни в Норильске, 1980-1985);

(13) 60, рабочий, №2, муж.: Это тоже. Вот / значит / он средний. Почему он средний? У него старания свои / свой ум позволил стать самим собою. ... ниже среднего. Который уже шикарный и в 18 лет на «мерседесе» ездит / это уже другой категории народ / это уже другое (Беседа с социологом на общественно-политические темы, Воронеж, 2003);

(14) 64, инженер, № 9, муж.: Которое было / оно до сих пор. Ну вся администрация президента (Беседа с социологом на общественно-политические темы, Москва, 2003).

Иногда наблюдается чередование ОМ кто и который и/или пре- и постпозиции:

(15) 45, воспитатель, № 8, жен.: А кто на заводе / на фабрике / в бюджетной сфере работают. Которые от бюджета зависят / от производства / 
которому не дают развиваться / тому хуже (Беседа с социологом на общественно-политические темы, Воронеж, 2003) ${ }^{3}$;

(16) 42, врач, № 1, муж.: Поэтому / я тоже немножко удаляюсь / встречаясь с таким ветераном / который начинает кричать / «Я кровь проливал». Которые кровь проливали / они в земле лежат сырой. А те / которые сейчас живы / в основном / это те / кто был в тылу. Боевых осталось очень мало. Они погибли или от ран / или от политики... (Беседа с социологом на общественно-политические темы, Самара, 2003);

(17) Журналист, Бачинский, муж.: Которые жирным шрифтом выделены / те уже бегали. А кто не жирным / тому можно звонить? Кому ты звонишь? (Передача «Утреннее шоу Бачинского и Стиллавина» на радиостанции «Максимум», 2006);

(18) 51, рабочий, № 5, муж.: Ну я хочу сказать / я считаю так / что расстреливали тех людей / которые были явные противники этого их строя / которым с ними / ну честно они чувствовали ихними соперниками. Заставить их работать / по-моему / было бесполезно. Их только нужно было убирать. С этой иелью их убивали. Которые просто ломались в лагерях / их отправляли работать / они работали (Беседа с социологом на общественно-политические темы, Москва, 2001).

Интересно отметить, что в трех последних примерах эксплицитно противопоставляются две референциальные группы выделенных ОК. Иногда действует эффект повтора предиката:

(19) 60, пенсионер, № 10, жен.: Они пройдут для нас еще ловчее. То есть / мы не поймем. Они проскочат. Которые стремятся к власти / они проскочаm (Беседа с социологом на общественно-политические темы, Новосибирск, 2003).

Обобщая эти наблюдения, можно отметить, что конструкция с ПОК имеет явно дискурсивную функцию: она выделяет обычную или контрастную тему в информационной структуре всего предложения. Этим, видимо, объясняется и почти исключительное употребление именительного падежа ${ }^{4}$. В ГК может появляться анафорическая ссылка независимо от роли данного актанта-постцедента: маркируется как субъект, так и существительное в косвенном падеже (примеры 7, 15, 17), причем даже актант в косвенном падеже может отсутствовать (пример 5). Не вполне ясно, как в синтаксическом представлении лучше моделировать отсутствие антецедента: с точки зрения нормативного построения ОК следовало бы отметить эллипсис

3 Здесь не совсем ясно, следует ли считать, что ОМ которому относится к антецеденту производства или что оно перефразирует Которые от бюджета зависят. В первом случае коррелят тому не согласуется по числу с ОМ которые, во втором которому является отклонением от правила, что ОМ выступает в им. п.

${ }^{4}$ В [НКРЯ] отмечены совсем немногочисленные примеры с внутренне несогласованной ИГ типа Которым дети седьмой год - сейчас они в эту субботу уезжают уже, приведенные в [Кручинина 1968: 85]. 
посредством знака ø, но можно и постулировать особую разговорную конструкцию без эллипсиса. Так или иначе, стоит подумать о том, трактовать ли отсутствие и присутствие антецедента как синтаксическое чередование в смысле, изложенном в [Апресян и др. 2010: 49]. В синтаксическом отношении подтип с анафорой в ГК представляет меньшую степень интеграции ОК в целом предложении, занимая как будто серединную позицию между сочинением и подчинением; в типологической литературе этот подтип хорошо известен под названием коррелятивный диптих [Lehmann 1988: 5]. В общем и целом языки с доминантной препозитивной конструкцией составляют в выборке языков, лежащей в основе типологического обзора [Dryer 2013], примерно одну четверть количества языков с постпозитивной моделью $(\mathrm{N}=141 / 579)$.

\section{Конструкции с именной вершиной в ОК}

Все рассмотренные до сих пор ОК были построены по схеме «субъект + предикат в виде глагольной группы, прилагательного (примеры $3,5,7,13$ ) или предложной группы (пример 8)». Встретились и два примера с именным предикатным словом (примеры 1,2$)$. Иначе обстоит дело в таких случаях, где в ОК выступает существительное вместе с глаголом:

(20) 84, пенсионер, респондент, жен.: Некоторые приезжали. Которые медсестры заканчивали / то приезжали сюда на практику / в больницу к нам. Хорошие... Знаете? А Вы не знаете. Раньше у всех были кальсоны / белье и в елочку / не трикотажные... Знаете? A Bы не знаете... (Биография (беседа лингвиста с информантом), 1997).

Этот пример допускает лишь такую интерпретацию, что медсестры функционирует как непосредственная вершина ОМ. Такое употребление фиксируют и [Зализняк, Падучева 1979: 294], которые характеризуют его как «просторечное»: Которые деньги были, он пропил. В [Кручинина 1968: 85] такие примеры приводятся без особой стилистической характеристики, например: Которые у нас жили дачники они в этот год не приехали.

Подобным образом следует, по-видимому, интерпретировать пример из хрестоматии [Шалина 2011: 83], с той разницей, что предшествует антецедент ней:
А.Ф. Я не знаю / с кем ты разговаривала //
Ф. П. Ну вот с ней / которая женщцна в очках ходит / беленькая.

В [Лаптева 1976: 144] приводятся десять примеров с именной вершиной в ОК, например:

(22) Я не смотрю на метки. Которые вот клиенты есть у меня, и тем я смотрю.

Автор усматривает в них модификации конструкции так называемого именительного темы. Она включает сюда же и примеры с антецедентом-коррелятом вроде: 
(23) Та, которая здесь стояла лампа, я ее не брал;

(24) Вот тем, которые ребята не подготовлены, тем приходилось туго.

Как видно, во всех трех примерах выступает еще анафорическая ссылка после ОК. Ввиду таких случаев следует, возможно, и пересмотреть оценку, данную следующему примеру в [Weiss 2019: 111], где говорится о возможном запоздавшем дополнении, т. е. о феномене речи:

В: Я ешё на хлеб горчииы намазал <...>

C: Дак а чё // мы тоже такие жрали / таки / эx //

B: А та / которая в баночке горчица / она слабенькая [Шалина 2011: 135].

Данный пример в принципе допускает двоякую интерпретацию: либо вся структура построена по модели примеров 23 и $24-$ с внутренней именной вершиной, либо она представляет включение ОК в именную группу та горчица, ср.:

1) $\left(\operatorname{det}\left(\operatorname{relpr}+\varnothing_{\text {быть }}+\operatorname{prepP}+\mathrm{N}\right)\right.$ Pron Adj либо

2) (det (relpr $+\varnothing_{\text {быть }}+$ prepP) N) Pron Adj

В свете вышеуказанных соображений первая интерпретация кажется теперь более убедительной.

Два примера с именной вершиной в ОК содержит сборник текстов, собранных в Воркуте, ср.:

(26) Те, которые люди работают на севере, живут здесь... и нельзя по врачебным этим соображениям выезжать и на юг отдыхать [Сергиева, Герд 1998: 74];

(27) В общем-то все, которые коми находятся или ненцы находятся в тундре, они все и члены колхозов [Там же: 396].

Даже [АГ 1980/2: 515] отмечает подобные построения, характеризуя их как «разговорные, особенно в просторечии» либо как прием стилизации: «по которой речке пльтьь — той и славушку творить», «На котором месте школа стоит, пустырь был». Здесь заметно отклонение от правила, что ОМ всегда оформляет субъект клаузы.

Итак, обнаружилась еще одна неканоническая, не совсем маргинальная конструкция ОК. Она отличается от нормативной модели наличием именной вершины ОМ в самой ОК. По ее позиционному поведению можно различить два подтипа: или вся ОК находится в препозиции, ср. примеры 20 и 22, или она вклинивается в главную клаузу между местоименным антецедентом и предикатом (все остальные вышеприведенные примеры). Во всех случаях ОМ выступает в именительном падеже - за исключением двух примеров из художественной литературы, приведенных в [АГ 1980].

Этим список неканонических конструкций еще не исчерпан. Так, диалектный материал подбрасывает нам еще один подвид конструкции с именной вершиной:

(28) Которы старухи не ушодии, так со старушками поговорить [Аванесов, Орлова 1964: 199]. 
Как видно, эта вершина здесь повторяется в ГК, создавая коррелятивный диптих. Можно было бы не упоминать об этом диалектном примере, если бы не попался подобный пример в хрестоматии [Шалина 2011: 216]:

(29) М. Tbl знаешь что есть такое кислит?

A. Hem

М. У него такая же формула как у мочевины / Токо называется по-другому / то есь это не та мочевина / которая мочевина у каждого есь.

В отличие от примера 28 ОК здесь выступает в постпозиции. Как уже отмечено в [Weiss 2019: 112], можно и здесь усмотреть эффект невнимательности говорящего. То же самое верно для единственного примера такого рода из устного корпуса [НКРЯ] (речь идет о бывшем генеральном прокуроре Скуратове):

(30) Когда уже человека убрали / когда доконали его. Только потому / что он начал вести / раскрывать какое-то очень серьезное дело / связанное с приватизацией. Которая вначале проводилась приватизация без всяких законов / без ничего. Все эти заводы покупались за какие-то там тысячные стоимости (Беседа с социологом на общественно-политические темы, Самара, 2003).

С другой стороны, в исторических текстах, относящихся к старорусскому периоду, именно этот подтип, с повторением определяемого слова, богато представлен [Борковский 1973], о чем свидетельствуют и многие примеры из [НКРЯ]; поэтому не исключено, что мы имеем дело с архаизмом, который кое-где еще сохранился в живой устной речи. Один из последних примеров, отмеченных в [НКРЯ], относится к 1776 г.:

(31) Богдановиче Милославском нарочно из Москвы присланным дьяком Иваном Гороховым сказаны были, который дыяк Горохов его ж боярские и сына его пожитки на его великого государя с дьяками, с Львом Нечаевым и с Никитою Полунинылм, в прошлом, 7185 году описывал и обирал (Н. И. Новиков, 1776).

Следовало бы также рассматривать примеры, где вершина внутри ОК состоит не из повтора, а из гиперонима существительного-антецедента: в [Холодилова 2014] приводится пример 1808 г. (пример 123), кроме того, упоминается эта модель и в [Зализняк, Падучева 1979: 293]. Так или иначе надо подчеркнуть, что сегодня подтип с повтором в постпозитивной ОК стилистически относится не к разговорной, а к формально-канцелярской разновидности языка.

Подытоживая результаты этого раздела, можно выделить еще один тип ОК, отличающийся от нормативной конструкции наличием непосредственной именной вершины ОМ, грамматически согласованной с ОМ. Во всех употреблениях ОМ опять-таки выступает в именительном падеже. По позиционному критерию нашлись три подвида: препозиция (ОК предшествует всей ГК), интерпозиция (ОК следует лишь за антецедентом) и постпозиция (ГК целиком предшествует ОК, ср. 
примеры 21, 29, 31). Среди постпозитивных употреблений нашлись два примера из современного узуса, где вершина повторяет существительное в ГК. Статус этих употреблений сомнителен, т. е. неизвестно, следует ли считать их случайными отклонениями или сохранившимся архаизмом, продолжающим исторически более распространенную модель. Как бы то ни было, здесь впервые представлено нерестриктивное (распространяющее) значение ОК (примеры 30, 31). Шире о данном подтипе пойдет речь в конце статьи.

В типологическом отношении описанная разновидность ОК соответствует типу конструкции с внутренней вершиной (internal head [Dryer 2013]), который как доминантная модель представлен лишь в неевропейских языках. Среди старорусских предшественников обсуждаемых конструкций с именной вершиной преобладает препозитивная модель с повторением вершины в ГК [Борковский 1973].

\section{Неканонические модели ОК в литературной стилизации: М. Зощенко}

После этого краткого обзора нестандартных конструкций ОК в разговорной разновидности русского языка небезынтересно взглянуть на способ, каким эти конструкции отражаются в художественных произведениях с подчеркнутой ориентировкой на устную спонтанную речь. Здесь напрашивается раннее сатирическое творчество М. Зощенко, которое изобилует ПОК, причем как в словах рассказчика, так и в речи персонажей: цитаты вроде Kоторые без денег - не ездют с дамами (Аристократка) общеизвестны среди русскоязычной образованной публики. Выборка произведений Зощенко в [НКРЯ] содержит 37 употреблений ПОК. По всей видимости, их частое употребление служит как художественный прием, особенно когда одна и та же номинация появляется несколько раз подряд. В следующем отрезке данный прием используется шесть раз:

(32) Которые с расхлябанной тарой, те, конечно, охают, ахают и страдают. Весовщик говорит: <..> И, которым отказали, - те смотрят на него с мольбой и предлагают ему свою дружбу и деньги за это самое. Но вот доходит очередь до одного гражданина. Он такой близорукий, в очках. <..> Который в очках, усльшиав эти слова, совершенно упадает духом. А перед тем, как упасть духом, до того набрасывается на весовщуика, что дело почти доходит до зубочистки. Который в очках кричит: - Да что тыл, собака, со мной делаешь! < ..> Он кричит: - Это как понимать? Не хочешь ли ты мне, очкастая кобыла, взятку дать?! Который в очках сразу, конечно, понимает весь позор своего положения. - Нет, - говорит, - я деньги вынул просто так <...> Который в очках, совершенно сопревиий, возится со свочми ящиками. Их ему укрепляют, приводят в христианский вид и снова волокут на весы (Слабая тара, 1930).

Как видно, здесь ПОК указывают сначала на группу лиц, которые определяются своей ролью в интеракции (которые с расхлябанной тарой, которым отказали), 
а потом из этой группы выделяется индивид, который четыре раза идентифицируется одним и тем же внешним признаком (который в очках). Групповая референция сопровождается еще и коррелятом те, при индивидуальной референции он отсутствует. Как показывает этот фрагмент, употребление ПОК не служит как можно более убедительной имитацией спонтанного узуса: этому противоречит, например, косвенный падеж в которым отказали и четырехкратное повторение одной и той же номинации, которая превращается как бы в лейтмотив. Косвенный падеж встречается и в следующем фрагменте:

(33) Не приходилось. Наоборот, которых встречал, все были такие милье, особенные (Честное дело, 1920-1930).

Интерес вызывает случай, где ОМ согласуется по падежу с соотносительным существительным, т. е. происходит полная интеграция ОК в ГК:

... спрашиваю: - Чего тут происходит? - этто, - говорят, - мы которых аристократов в грузовик сажаем и арестовываем. Ликвидируем этот класс. И вдруг вижу я - ведут. Бывшего графа ведут в мотор (Жертва революции, 1923).

Таким образом, в ИГ которых аристократов стягиваются элементы тех, коmорые аристократы. Как и в случае с примерами 1, 2, ОМ здесь оказывается избыточным, достаточно было бы сказать «мы аристократов сажаем». Подобный пример приводится в [Холодилова 2014: пример 90]: Позвали бы которых поумнее $\kappa$ себе... (М. Горький, 1906), с той разницей, однако, что на этот раз ОМ необходим, ср. * позвали бы поумнее к себе; это, по всей видимости, обусловлено отсутствием падежной маркировки в словоформе поумнее, см. выше пример 3.

Употребление референциального «лейтмотива» (см. пример 32) характерно и для других рассказов. Так, в «Тормозе Вестингауза» (1926) один референт вводится в форме какой-то в синем картузе, а потом упоминается четыре раза как Который в синем картузе; в разговоре участвует еще дважды референт $У$ которого вата в ухе. С другой стороны, функция лейтмотива может и сочетаться с антецедентом, образуя нерестриктивную постпозитивную ОК: это наблюдается в известном рассказе «Нервные люди» (1925), где посессор ежика вводится как Дарья Петровна Кобылина, чей ежик, потом меняется на Муж, Иван Степаныч Кобылин, чей ежик и, наконец, на Иван Степаныч, чей ежик.

Референциальное противопоставление с помощью ПОК иногда принимает особый вид:

(35) Мало. Для наглядности не менее как сорок требуется. И приперлись эти артисты на спектакль со своими запасами. Которые горькую принесли, которые - пиво. А некоторые и самогону раздобыли (Фельетоны, 19231929).

Здесь ОМ явно функционирует как синоним одни - другие.

Препозитивные ОК могут и чередоваться с обычными референциальными ИГ: 
(36) Или бы так: научных секретарей вселять, скажем, к научным секретарям. Академиков, прочедиих чистку аппарата, - какадемикам. Зубных врачей - к зубным врачам. Которые на флейте свистят - опять же к свочм ребятам, - вали свисти вместе! Ну, конечно, если нельзя иметь такую точность при вселении, то и не надо. Пущай бы по главным признакам вселяли. Которые люди умственного труда и которые любят по ночам книжки перелистывать - вали к свочм ночным труженикам. Другие - к другим. Третьи - к третьим. <... Вот я и говорю: ученых секретарей надо к ученым секретарям, зубных врачей к зубным врачам и так далее. А которые на флейте свистят, тех можно за городом поселить. Вот тогда жизнь засияет в полном своем блеске (Мерси, 1920-1930).

Коррелят тех после последней ОК как будто закругляет этот список, маркируя его конец. Такое чередование может иметь место в непосредственном соседстве:

(37) Или пущаай администрацчи пересаживает публику по ранжиру: высоких взад, которые низенькие, пущай вперед садятся (Фельетоны, 1923-1929).

Опять заметен отказ от параллелизма (высоких взад, низенькие вперед садятся), обусловленный, возможно, изменением предикации и синтаксической ролью актантов у низеньких.

Как и в живом узусе, наличие ИГ в ОК требует двоякой интерпретации. С одной стороны, ИГ может играть роль предикатного слова, как в примерах 1 и 2, ср.:

(38) Ну, - говорю ему, - как вообще, что пишут, велики ли заработки?- Заработки, говорит, невелики, но которые интеллигентные больные и хотя бы при смерти, норовят непременно в руку сунуть. - Извольте, говорю, хотя и не при смерти, но дать не отказываюсь (Плохой обычай, 19201930).

С другой стороны, [НКРЯ] содержит и три употребления из рассказов Зощенко, где ОМ зависит от именной вершины в самой ОК:

(39) Летний сезончик не был выдающимся. Которые товарищи актеры приезжают из провинции, те все зубами скрипят. - Прямо, говорят, для себя играли - нема никакой публики (Театр для себя, 1920-1930);

(40) Конечно, слов нет, стремянка не была сплочной чистоты - не блестела. И в ведрышко - раз в нем краска - нельзя свои польты окунать. И которая дама сунула туда руку - сама, дьявол ее задави, виновата. Не суй рук в чужие предметы! (Мещанский уклон, 1926);

(41) Это будет рассказ про нэпмана. Которые пролетарии не хотят про это читать - пушай не читают. Мы не настаиваем! На лестнице. Происходит звонок, и в квартиру входит обыкновенный человек и заявляет: - Я агент Гепеу. Не бойтесь! Который тут нэпман Егор Горбушкин - пущзай живо собирается и идет со мной. Вот мандат и повестка (Спешное дело, 1920-1930). 
Отметим, что ИГ нэпман Егор Горбушкин здесь оформляет предикат.

Итак, оказывается, что тип конструкции ПОК с именной вершиной, который в живой речи был представлен в примерах 20 и 22, не чужд и творчеству Зощенко. Следует подчеркнуть, что постпозитивный подтип с повторением именной вершины (см. выше примеры 28-31) в нашей выборке рассказов Зощенко не отмечен, что, скорее всего, объясняется его принадлежностью к формальному письменному стилю. Основная дискурсивная функция всех рассмотренных фрагментов из рассказов Зощенко, таким образом, весьма одинакова: ОК служит для выделения темы, а кроме того, как и в живой речи, конструкция позволяет противопоставлять два или больше референтов. Особой чертой авторского идиостиля является функция лейтмотива, т. е. постоянного повторения той же номинации. Подчеркнем, что другие оформления ОК, характерные для разговорного узуса, у Зощенко совсем не представлены; это верно для ОК с перемещенным ОМ типа Посмелее которые опять смеются, а особенно для конструкции без ОМ типа Убери очки Ваня оставил [ср.: АГ 1980/2: 647; Земская 1973; Земская и др. 1981; Кручинина 1968: 85 и след.; Холодилова 2014; Ширяев 1986; Miller, Weinert 1998; Murelli 2011; Woolhiser 1990]. Другими словами, автор выбирает лишь один из разных возможных приемов для создания эффекта спонтанной речи.

В заключение хотелось бы указать на параллельный случай стилизации неканонической конструкции ОК у других, более современных писателей. Речь идет о постпозитивной ОК с повторением именной вершины, как в примерах 30 и 31 . Эта разновидность отличается от остальных рассмотренных типов ОК, как уже отмечалось, в трех отношениях: она оформляет нерестриктивные ОК, относится к формальным регистрам письменного узуса, точнее имеет «архаично-канцелярский привкус» [Норман 2012], и считается устарелой. Тем не менее она переживает как бы свое воскресение в творчестве Л. Петрушевской. Из многочисленных примеров, приведенных в [Норман 2012], укажем на следующий (повтору здесь подвергается не вся ИГ-антецедент, а лишь ее вершина):

(42) Поначалу никто не обратил внимания на поломанную ножку кровати, покосившийся унитаз и битые тарелки в мусорном ведре, которое ведро никто не выносил со дня отъезда (Морские помойные рассказы, 2011).

Как убедительно формулирует Б. Норман, «это риторическая фигура, нацеленная на заигрывание с читателем, своего рода речевое манерничанье». Подобную функцию можно приписать употреблению ПОК в творчестве Зощенко, хотя стилистическое расстояние между художественным приемом и его источником в живой речи там гораздо менее значительно, чем в случае Л. Петрушевской.

${ }^{5}$ Отметим, что такие построения нарушают конструктивную особенность Релятивного СинтО, что «вершине придаточного < .. > обязательно подчиняется одно из союзных слов который» и т. д. [Апресян и др. 2010: 33]. Поэтому они (в отличие от ОК без антецедента) однозначно требуют создания особой СинтО. 


\section{Литература}

Аванесов Р. И., Орлова В.Г. Русская диалектология. М. : Наука, 1964. 305 с.

АГ 1980 - Русская грамматика : в 2 т. / гл. ред. Н. Ю. Шведова. М. : Наука, 1980.

Апресян Ю.Д., Богуславский И. М., Иомдин Л. Л., Санников В. 3. Теоретические проблемы русского синтаксиса. Взаимодействие грамматики и словаря. М. : Языки славянских культур, 2010. 407 с.

Борковский 1973 - Сравнительно-исторический синтаксис восточно-славянских языков. Сложноподчиненное предложение / отв. ред. В.И. Борковский. М. : Наука, 1973. 356 с.

Зализняк А.А., Падучева Е.В. Синтаксические свойства местоимения котоpый // Категория определенности-неопределенности в славянских и балканских языках / отв. ред. Т. М. Николаева. М. : Наука, 1979. С. 289-329.

Земская 1973 - Русская разговорная речь / отв. ред. Е.А. Земская. М. : Наука, 1973. $485 \mathrm{c}$.

Земская Е.А., Китайгородская М.В., Ширяев Е.А. Русская разговорная речь: Общие вопросы. Словообразование. Синтаксис. М. : Наука, 1981. 278 с.

Китайгородская М.В., Розанова Н. Н. Речь москвичей. Коммуникативно-культурологический аспект. М. : Русские словари, 1999. 396 с.

Кручинина И. Н. Конструкции с местоимением «который» в современном русском языке // Вопросы языкознания. 1968. №2. С. 82-88.

Лаптева О.А. Русский разговорный синтаксис. М. : Наука, 1976. 397 с.

HКРЯ - Национальный корпус русского языка [Электронный ресурс]. URL: http://ruscorpora.ru

Норман Б.Ю. Об одной особенности идиостиля Людмилы Петрушевской // Жанры речи. Вып. 8. Памяти К. Ф. Седова / отв. ред. В. В. Дементьев. Саратов ; М. : Лабиринт, 2012. С. 226-332.

Сергиева Н. С., Герд А. С. Русская разговорная речь европейского Северо-Востока России: сб. текстов. Сыктывкар : Сыктывкар. гос. ун-т, 1998. 158 с.

Шалина 2011 - Живая речь уральского города: устные диалоги и эпистолярные образцы : хрестоматия / сост. И.В. Шалина. Екатеринбург : Изд-во Урал. унта, $2011.360 \mathrm{c}$.

Холодилова М.А. Относительные придаточные. 2014 [Электронный ресурс]. URL: http://rusgram.ru/Относительные_придаточные

Ширяев Е.Н. Бессоюзное сложное предложение в русском языке. М. : Наука, 1986. $223 \mathrm{c}$.

Dryer M.S. Order of Relative Clause and Noun // The World Atlas of Language Structures Online / ed. by M. S. Dryer, M. Haspelmath. Leipzig : Max Planck Institute for Evolutionary Anthropology, 2013 [Электронный pecypc]. URL: https://wals.info/ chapter/90 
Lehmann Ch. Towards a typology of clause linkage // Typological Studies in Language - 18 / ed. by E. Haiman, S. A. Thompson. Amsterdam ; Philadelphia : John Benjamins, 1988. P. 181-226.

Miller J., Weinert R. Spontaneous Spoken Language. Syntax and Discourse. Oxford : Clarendon Press, 1998. 457 p.

Murelli A. Relative Constructions in European Non-Standard Varieties. Berlin : De Gruyter Mouton, 2011. $477 \mathrm{p}$.

Weiss D. Zero Linking in Russian Colloquial Relativization // Zeitschrift für Slavische Philologie. 2019. № 1. P. 95-122.

Woolhiser C. "Missing Prepositions" in colloquial Russian relative clauses // Topics in Colloquial Russian / ed. by M.H. Mills. New York : Lang, 1990. P. 17-30.

\section{Daniel Weiss}

University of Zurich, Slavic Department

(Switzerland, Zurich)

dawe@slav.uzh.ch

\section{CONSTRUCTIONS WITH PREPOSED RELATIVE CLAUSES}

The paper examines two types of non-canonical restrictive relative sentences in contemporary colloquial Russian: preposed relative clauses with the pronoun kotoryj 'which' and relative clauses with internal head. The first type fulfils a clear discursive function since the relative clause serves here to mark a neutral or contrastive theme. This explains the exclusive use of the nominative case of the pronoun. The main clause often contains an anaphoric support of the relative clause by means of a personal or demonstrative pronoun; such a support is however not mandatory. The construction with internal head mainly functions in pre- or interposed relative clauses. Two examples with postposition and repetition of the antecedent had non-restrictive reference; their acceptability is however questionable since they may be due to an accidental uncontrolled deviation from the norm. On the other hand, it should be pointed out that in historical official or bureaucratic sources this subtype was quite widespread (the following quotation might illustrate the case: "And which peasant brews bear illegally, this peasant shall pay a fine") and may even today be used as an intended playful archaism: this device is notably used in L. Petrushevskaya's work. The last section of the paper discusses the use of preposed relative clauses in the speech of the narrator and the main characters in M. Zoshchenko's tales. Here, this device is not meant to imitate the authentic usage as faithfully as possible, but merely as an artistic stylization of oral speech. This may be seen from the lack of other non-canonical patterns of relative clauses known from authentic speech and above all from the frequent repetitions of certain relative clauses intended as a leitmotiv for the characterization of the given character. All examples are taken from the basic 
and oral subcorpora of the Russian national corpus, the collection of texts Zhivaya rech' ural'skogo goroda and the available descriptions of Russian colloquial speech. The empirical findings are complemented by typological notes.

Keywords: Relative clause, preposed clause, theme, Russian colloquial speech, internal head, antecedent, anaphora, M. Zoshchenko, artistic device.

\section{References}

Apresyan Yu.D., Boguslavskii I.M., Iomdin L.L., Sannikov V.Z. Teoreticheskie problemy russkogo sintaksisa. Vzaimodeistvie grammatiki $i$ slovarya [The Theoretical problems of Russian syntax. The Interaction of grammar and dictionary]. Moscow, Yazyki slavyanskikh kul'tur Publ., 2010. 407 p.

Avanesov R.I., Orlova V.G. Russkaya dialektologiya [Russian dialectology]. Moscow, Nauka Publ., 1964. 305 p.

Borkovskii V.I. (Ed.). Sravnitel'no-istoricheskii sintaksis vostochno-slavyanskikh yazykov. Slozhnopodchinennoe predlozhenie [The Comparative-historical syntax of Eastern Slavic languages. Complex sentences]. Moscow, Nauka Publ., 1973. 356 p.

Dryer M. S. Order of Relative Clause and Noun. The World Atlas of Language Structures Online. M.S. Dryer, M. Haspelmath (Eds.). Leipzig, Max Planck Institute for Evolutionary Anthropology, 2013. Available at: https://wals.info/chapter/90 (accessed 22.02.2020)

Kholodilova M.A. Otnositel'nye pridatochnye [Relative sentences] Available at: http://rusgram.ru/Otnositel'nye_pridatochnye (accessed 22.02.2020)

Kitaigorodskaya M.V., Rozanova N.N. Rech' moskvichei. Kommunikativnokul'turologicheskii aspect [The Speech of Muscovites. The Communicative-culturological aspect]. Moscow, Russkie slovari Publ., 1999. 396 p.

Kruchinina I.N. [Constructions with the pronoun kotoryj 'which' in the modern Russian language]. Voprosy yazykoznaniya, 1968, no. 2, pp. 82-88. (In Russ.)

Lapteva O.A. Russkii razgovornyi sintaksis [Russian colloquial syntax]. Moscow, Nauka Publ., 1976. 397 p.

Lehmann Ch. Towards a typology of clause linkage. Typological Studies in Language - 18. E. Haiman, S. A. Thompson (Eds.). Amsterdam, Philadelphia, John Benjamins, 1988, pp. 181-226.

Miller J., Weinert R. Spontaneous Spoken Language. Syntax and Discourse. Oxford, Clarendon Press, 1998. 457 p.

Murelli A. Relative Constructions in European Non-Standard Varieties. Berlin, De Gruyter Mouton, 2011. 477 p.

Natsional'nyi korpus russkogo yazyka [The National corpus of the Russian language]. Available at: http://ruscorpora.ru (accessed 22.02.2020)

Norman B.Yu. [On a particularity of Ljudmila Petrushevskaya's individual style]. Zhanry rechi. Vyp. 8. Pamyati K.F. Sedova [The Genres of speech. A Collection of scientific papers, Iss. 8. In memory of K. F. Sedov]. V. V. Dement'ev (Ed.). Saratov, Moscow, Labirint Publ., 2012, pp. 226-332. (In Russ.) 
Sergieva N. S., Gerd A. S. Russkaya razgovornaya rech' evropeiskogo Severo-Vostoka Rossii: sb. tekstov [Russian colloquial speech of the European north-east of Russia: a collection of texts]. Syktyvkar, Syktyvkar St. Univ. Publ., 1998. 158 p.

Shalina I. V. (Ed.). Zhivaya rech' ural'skogo goroda: ustnye dialogi i epistolyarnye obraztsy: khrestomatiya [Authentic speech of the Ural cities: oral dialogues and selected letters. An anthology]. Ekaterinburg, Ural St. Univ. Publ., 2011. 360 p.

Shiryaev E. N. Bessoyuznoe slozhnoe predlozhenie v russkom yazyke [Asyndetic complex sentences in Russian]. Moscow, Nauka Publ., 1986. 223 p.

Shvedova N.Yu. (Ed.). Russkaya grammatika [Russian grammar]. Moscow, Nauka Publ., 1980. Vols. 1-2.

Weiss D. Zero Linking in Russian Colloquial Relativization. Zeitschrift für Slavische Philologie, 2019, no. 1, pp. 95-122.

Woolhiser C. "Missing Prepositions" in colloquial Russian relative clauses. Topics in Colloquial Russian. M. H. Mills (Ed.). New York, Lang, 1990, pp. 17-30.

Zaliznyak A. A., Paducheva E. V. [Syntactic properties of the pronoun kotoryj 'which']. Kategoriya opredelennosti-neopredelennosti v slavyanskikh i balkanskikh yazykakh [The category of definiteness-indefiniteness in the Slavic and Balkan languages]. T. Nikolaeva (Ed.). Moscow, Nauka Publ., 1979, pp. 289-329. (In Russ.)

Zemskaya E.A., Kitaigorodskaya M.V., Shiryaev E.A. Russkaya razgovornaya rech': Obshchie voprosy. Slovoobrazovanie. Sintaksis [Russian colloquial speech: General aspects. Word formation. Syntax]. Moscow, Nauka Publ., 1981. 278 p.

Zemskaya E. A. (Ed.). Russkaya razgovornaya rech' [Russian colloquial speech]. Moscow, Nauka Publ., 1973. 485 p. 